\title{
Development of novel microsatellite markers for effective applications in Anthurium cultivar identification
}

\author{
Jau-Yueh Wang $\cdot$ Keng-Chang Chuang
}

Received: 2 February 2012/Accepted: 12 September 2012/Published online: 23 September 2012

(C) The Author(s) 2012. This article is published with open access at Springerlink.com

\begin{abstract}
Anthurium andraeanum is one of the most economically important floral crops and potted flowers marketed worldwide. Microsatellite markers are currently the preferred molecular marker owing to the many desirable attributes, including hypervariability, codominance, and amenability to high-throughput genotyping; however, there are few polymorphic molecular markers available for Anthurium. The object of this study was to develop and characterize novel microsatellite markers using the Araceae sequences in GenBank of the National Center for Biotechnology Information (NCBI) to contribute to molecular identification for cultivar protection. Using 1,579 Araceae expressed sequence tags (ESTs) and the related nucleotide sequences, 100 candidates contained simple sequence repeat (SSR) motifs that were suitable for primer design. Furthermore, 100 pairs of SSR primers were screened against a set of 28 diverse genotypes representing 24 cultivars that included four registration cultivars which were bred from the Taiwan Agricultural Research Institute (TARI) and 20 commercial cultivars, appended with three hybrid
\end{abstract}

J.-Y. Wang

Biotechnology Division, Agricultural Research Institute, COA, 189 Chung-Cheng Rd., WuFeng, Taichung, Taiwan

K.-C. Chuang ( $\square)$

Breeding Department, Floriculture Research Center, Agricultural Research Institute, COA, WuFeng, Taichung, Taiwan

e-mail: keng4891@ tari.gov.tw progeny and a mutant line. From the selected six polymorphic SSR loci, 52 alleles were amplified and 27 distinct genotypes were found, except for 'Tropical' and its mutant, with a mean number of eight alleles per locus. The polymorphism information content (PIC) ranged from 0.86 to 0.93 . Based on these results, we proposed a key identification set using four microsatellite markers that is sufficient to discriminate among 24 cultivars. Because the Anthurium microsatellite markers developed in this study are primarily from expressed sequence tags or related genomic sequences, they can be used for cultivar identification and, accordingly, contribute to genetic evaluations in breeding programs.

Keywords Anthurium - Expressed sequence tags . Microsatellite marker $\cdot$ Cultivar identification

\section{Introduction}

Anthurium andraeanum is a perennial flower of the Araceae family plants that are suitable for growth in subtropical regions. Among Anthurium, approximately 20 species can be used as ornamental plants, with Anthurium andraeanum being the most popular for potted plants and cut flowers (Henny et al. 1988; Kamemoto and Kuehnle 1996). According to the statistics of 2006 from the Dutch Flowers Auctions Association (VBN), Anthurium was ranked fourth as 
an economic potted plant, after phalaenopsis, chrysanthemum, and kalanchoe. Since 1997, the Taiwan Agricultural Research Institute (TARI) has enhanced breeding programs in response to market demands; aiming to promote the diversification of flower types and colors, the stability of the year-round quality, and cultivation adaptability. Six new cultivars have been registered from 2006 to date. However, effective molecular markers need to be established to assist the genetic background analysis and hybrid selection in this breeding program. In addition, specific molecular markers can establish the identity of the registration material and cultivar protection.

In recent years, biotechnology has developed rapidly, and molecular markers have become important tools in genetic research and assist in breeding efficiency. Among them, simple sequence repeat (SSR) markers are relatively abundant in plant genomes (Condit and Hubbell 1991; Wang et al. 1994); these markers show hypervariability, are multiallelic in nature, representing codominant genetic traits, and are suitable for high-throughput analysis (Rajwant et al. 2011). SSR markers have been widely applied to construct linkage maps of the rice (McCouch et al. 2002) and tomato (Frary et al. 2005) genomes. Such markers can also be used to assist in selection in breeding and backcrossing for a specific trait or quantitative traits, in genotyping species (He et al. 2003; Gong and Geng 2010; Zorrilla-Fontanesi et al. 2011), and in cultivars identification (Tantasawat et al. 2010; Zhang et al. 2010) and serve as effective tools in plant germplasm diversity analysis (Guilford et al. 1997; Gomez et al. 2008; Mujaju et al. 2010).

There have been relatively few reports regarding the use of molecular markers to characterize genetic variation within Anthurium cultivars. Isozymes were the first molecular marker used for genotypic characterization in Anthurium (Kobayashi et al. 1987), yet those markers are very limited and display low polymorphism. Since then, a number of genomic markers based on DNA polymorphism, such as random amplified polymorphic DNA (RAPD) and inter simple sequence repeat (ISSR) molecular markers, have been developed and used for genetic diversity analyses (Wang et al. 2001; Nowbuth et al. 2005). However, RAPD and ISSR markers are dominant, limiting their use for population genetic studies. Additionally, the RAPD markers are also sensitive to the reaction conditions, interfering with the reproducibility of banding patterns between experiments. The present study aims at mining the genomic information of Anthurium and other Araceae genera for developing novel and specific SSR markers and to select critical markers for fingerprint analyses in the future. For this purpose, we screened the NCBI GenBank of publicly available nucleotide sequences and expressed sequence tags (ESTs) for the SSR motifs, designed flanking primer pairs to amplify the SSR-containing markers, evaluated a key subset of polymorphic primers for the identification of cultivars, and tested the marker transferability across the Araceae family.

\section{Materials and methods}

\section{Plant materials and DNA extraction}

Twenty-eight genotypes of Anthurium spp., including four new cultivars ('TN01 Pink Panther', 'TN02 Orange Storm', 'TN03 Green Elf', and 'TN04 Pink Girl') which had been bred by the TARI, four comparison cultivars ('Marian Seefurth', 'Nette', 'Midori', and 'Lunette'), 16 commercial cultivars, three hybrid progeny, and a mutation of 'Tropical' (Tropical-P), were selected as the test materials (Table 1).

The genomic DNA of the 28 genotypes had been isolated from young leaves following the CTAB method described by Iqbal et al. (1995) with some modifications. For each sample, approximately $100 \mathrm{mg}$ of fresh tissue was homogenized with $1 \mathrm{ml}$ of CTAB extraction buffer ( $2 \%$ CTAB, 100 mM Tris$\mathrm{HCl}$ [pH 8.0], 20 mM EDTA [pH 8.0], 1.4 M NaCl, and $0.1 \% \beta$-mercaptoethanol), placed into a $1.5 \mathrm{ml}$ Eppendorf tube and incubated at $65{ }^{\circ} \mathrm{C}$ for $30 \mathrm{~min}$. To each tube, $500 \mu \mathrm{l}$ of 24:1 chloroform/isoamyl alcohol was added, and the solution was vortexed and centrifuged at 13,000 rpm for $10 \mathrm{~min}$. The DNA was then precipitated by mixing $500 \mu \mathrm{l}$ supernatant with an equal volume of isopropanol, incubating at $4{ }^{\circ} \mathrm{C}$ for $1-2 \mathrm{~h}$ and then centrifuging at 13,000 rpm for $5 \mathrm{~min}$. The DNA pellet was washed with $75 \%$ ethanol, dried to remove the alcohol, and dissolved in $100 \mu \mathrm{l}$ water at $4{ }^{\circ} \mathrm{C}$ overnight. Lastly, the supernatant containing the DNA was collected after microcentrifugation at $12,000 \mathrm{rpm}$ for $5 \mathrm{~min}$ and diluted to a concentration approximately $50 \mathrm{ng} / \mu \mathrm{l}$ for the PCR reaction. 
Table 1 The plant materials of Anthurium spp. and their inflorescent characteristic used in the identification of simple sequence repeats (SSRs) a TARI: Taiwan Agricultural Research Institute

b Tropical-P is a mutant from the Tropical

\begin{tabular}{|c|c|c|c|c|}
\hline $\begin{array}{l}\text { Cultivar/ } \\
\text { genotype }\end{array}$ & Spathe Color & $\begin{array}{l}\text { Spadix } \\
\text { Color }\end{array}$ & $\begin{array}{l}\text { Peduncle } \\
\text { Color }\end{array}$ & Origin \\
\hline Acropolis & White & Yellow & Green & Anthura (Netherlands) \\
\hline Alexis & Red & Green & Green & AVO (Netherlands) \\
\hline Anneke & Salmon & Yellow & Brown & AVO (Netherlands) \\
\hline Atlantis & Red & Yellow & Brown & Unknown \\
\hline Carnaval & White and red boder & Yellow & Brown & Anthura (Netherlands) \\
\hline Champion & White and red vein & Red & Green & Anthura (Netherlands) \\
\hline Cuba White & White & Green & Green & AVO (Netherlands) \\
\hline Fantasia & Cream and red vein & Red & Green & Anthura (Netherlands) \\
\hline Fla-Exotic & White and red boder & Yellow & Brown & Flamingo (Netherlands) \\
\hline Lady Jane & Pink & Pink & Green & Florida University \\
\hline Lunette & Pink & Pink & Brown & AVO (Netherlands) \\
\hline Marian Seefurth & Pink & Green & Green & Hawaii University \\
\hline Merengue & White & Pink & Green & Anthura (Netherlands) \\
\hline Midori & Green & Green & Green & Anthura (Netherlands) \\
\hline Sonate & Pink & Pink & Green & Anthura (Netherlands) \\
\hline Southern Blush & Purple & Pink & Brown & Florida University \\
\hline TN01 & Obake Pink & Green & Green & TARI $^{\mathrm{a}}$ \\
\hline TN02 & Obake Orange & Yellow & Brown & TARI \\
\hline TN03 & Green & Green & Green & TARI \\
\hline TN04 & Obake Pink & Pink & Green & TARI \\
\hline Tropical & Red & Green & Green & Anthura (Netherlands) \\
\hline Tropical- $\mathrm{P}^{\mathrm{b}}$ & Pink & Green & Green & Tropical mutation \\
\hline Tulip & Pink & Pink & Green & Unknown \\
\hline Champagne & Cream & Green & Green & Anthura (Netherlands) \\
\hline 123(Nette) & Orange & Yellow & Brown & AVO (Netherlands) \\
\hline 943954-1 & White & Yellow & Green & TARI \\
\hline $943954-2$ & White & Yellow & Green & TARI \\
\hline $943954-4$ & White & Yellow & Green & TARI \\
\hline
\end{tabular}

SSR motif search and primer design

A set of 55 nucleotide sequences of Anthurium from NCBI (GenBank) were screened for the presence of perfect SSRs using a combination of a simple sequence repeat identification tool (SSRIT, Temnykh et al. 2001) and primer 3 (Rozen and Skaletsky 2000). In the present study, a microsatellite was defined as a DNA sequence containing at least 15 repeated units for mononucleotide repeats, seven units for dinucleotide repeats, and four units for tri-, tetra-, penta-, and hexa-nucleotide repeats. All of the primers were designed using the following parameters: (1) a minimum of seven dinucleotide or five trinucleotide repeats in the ESTs; (2) a primer length of 18-27 nucleotides (nt), with $20 \mathrm{nt}$ considered optimal; (3) expected PCR products between 80 and $400 \mathrm{bp}$; (4) an optimal annealing temperature $60{ }^{\circ} \mathrm{C}$, and (5) a GC contents from 20 to $80 \%$, with $50 \%$ as the optimum.

A total of 32 Colocasia esculenta microsatellite sequences were searched in GenBank to verify for a number of repeats and motifs. SSR primers flanking the repeat sequences were designed using the primer3 software program. These primers were used to assess the transferability to reveal genetic polymorphisms in Anthurium.

We screened 1,492 Zantedeschia aethiopica ESTs available at NCBI (GenBank) for di-, tri-, tetra-, and penta-nucleotide motifs in microsatellite containing $\geq 15$ base pairs (bp) and hexa-nucleotide motifs 
$\geq 18 \mathrm{bp}$, using a combination of msatcommander (Faircloth 2008) and primer3 (Rozen and Skaletsky 2000). Sufficient flanking sequences of appropriate quality for primer design were screened, and the polymorphisms among 28 genotypes of Anthurium were characterized.

Polymerase chain reaction (PCR) amplification and SSR markers selection

The PCR reactions were performed in 96 well plates using the Perkin Elmer Cetus Thermal Cycler 9700 (Applied Biosystems) amplification program. Each $25 \mu \mathrm{l}$ reaction mixture contained $50 \mathrm{ng}$ Anthurium genomic DNA, $0.4 \mu \mathrm{M}$ forward and reverse primers, $200 \mu \mathrm{M}$ each dNTP, $2.5 \mu \mathrm{l}$ 10X PCR buffer containing $50 \mathrm{mM}$ Tris- $\mathrm{HCl}$ [pH 8.3], $50 \mathrm{mM} \mathrm{KCl}, 50 \mathrm{mM}$ $\left(\mathrm{NH}_{4}\right) \mathrm{SO}_{4}$, and 1 unit Taq DNA polymerase (RocheFastStart). The PCR amplification conditions were programmed as one cycle of denaturation at $95{ }^{\circ} \mathrm{C}$ for 5 min, followed by 35 cycles with a $45 \mathrm{~s}$ denaturation at $94{ }^{\circ} \mathrm{C}$, a $25 \mathrm{~s}$ annealing at the $\operatorname{Tm}\left(\operatorname{Tm} 55-60{ }^{\circ} \mathrm{C}\right.$, adjusted to the individual primers) and a $45 \mathrm{~s}$ extension at $72{ }^{\circ} \mathrm{C}$. The final extension was at $72{ }^{\circ} \mathrm{C}$ for 8 min.

The PCR products were separated by electrophoresis on $6 \%$ polyacrylamide gels in $0.5 \mathrm{X}$ TBE buffer (40 mM Tris acetate [pH 8.0] and $1 \mathrm{mM}$ EDTA) at a constant power of $90 \mathrm{~V}$ for 60 min using a MGV-20233 (C. B. S. SCIENTIFIC) apparatus. The gels were stained with ethidium bromide $(1 \mu \mathrm{g} / \mathrm{ml})$ and visualized under UV light using an IS 2000 Digital Imaging System (Alpha Innotech.). A 25 bp DNA Step Ladder (Promega) and a Low Molecular Weight DNA Ladder (NEB) were used as the molecular size standard.

Data analysis

All 28 Anthurium genotypes were used to screen for SSR primers, PCR amplification, and product-length polymorphisms. For the primers that produced the expected PCR product size, the number of alleles was recorded, and the polymorphism information content (PIC) of each SSR locus was calculated as described by Saal and Wricke (1999). The genetic similarity coefficient estimation was based on the method described by Nei and Li (1979). Furthermore, 28 Anthurium genotypes were clustered based on the estimated Dice's similarity coefficient. The phylogenetic tree (or dendrogram) was inferred using the BioNumerics Software (Applied Math), and the clustering method of the Un-weighted Pair Group Method Using Arithmetic Average (UPGMA).

\section{Results}

Development of novel Anthurium SSR markers

A total of eight (14.5\%) SSR-containing primers were designed from 55 nucleotide sequences of Anthurium. Of these, six primer pairs (Am1-Am3 and Am6-Am8) contained dinucleotide repeat motifs (75\%), and two primers (Am4 and Am5) contained trinucleotides motifs (Table 2). When the eight working SSR primer pairs were further tested using the 28 genotypes, four loci $(50 \%)$ were able to produce the expected PCR products, whereas the other four failed to amplify the expected fragments. All of the 4 amplified loci revealed polymorphisms and detected 40 alleles, and the amplicon size ranged from 92 to $200 \mathrm{bp}$ (Table 2). The number of alleles at each polymorphic SSR locus ranged from 9 to 11, with an average of 10 alleles (Table 2). The PIC value of SSR markers was from 0.87 to 0.93 (Table 2). SSR-PCR profiles obtained from the 4 loci of Am2, Am7, and Am8 were clear and easy to interpret (Fig. 1).

All of the target sequences of thirty-two primer pairs designed from the 32 Colocasia esculenta microsatellite sequences contained dinucleotide repeat motifs. Among them, 25 of the SSR-primers contained dinucleotides of perfect/compound repeats, and seven primers contained interrupted compound dinucleotide repeats. Testing the 28 genotypes of Anthurium using the 32 SSR-primers of Colocasia esculenta revealed that only locus $\mathrm{Cm} 16$ was able to produce the expected PCR products with polymorphisms, with 9 polymorphic alleles being detected and fragment sizes of 206-299 bp. Moreover, the locus of Cm16 was highly polymorphic, with a PIC value of 0.9 , and the profile was easy to interpret (Table 2; Fig. 1).

Transferability of Zantedeschia SSR markers for Anthurium

Of the 1,492 Zantedeschia aethiopica EST sequences, sufficient flanking sequences of appropriate quality for SSR primers design were present in 350 unigenes 
Table 2 Microsatellite primer sequences and characteristics of the SSR markers developed from the GenBank sequences of Anthurium, Colocasia esculenta and Zantedeschia aethiopica

\begin{tabular}{|c|c|c|c|c|c|c|c|}
\hline $\begin{array}{l}\text { Locus and } \\
\text { GenBank } \\
\text { accession no. }\end{array}$ & Repeat motif & Primer sequences $5^{\prime} \rightarrow 3^{\prime}$ & $\begin{array}{l}\text { SSR } \\
\text { location }\end{array}$ & $\begin{array}{l}\text { Expected } \\
\text { size (bp) }\end{array}$ & $\begin{array}{l}\text { Product } \\
\text { size (bp) }\end{array}$ & $\begin{array}{l}\text { Allele } \\
\text { no. }\end{array}$ & PIC \\
\hline $\begin{array}{l}\text { Am1 } \\
\text { (AY054729) }\end{array}$ & $(\mathrm{AT})_{17}$ & $\begin{array}{l}\text { F: TCCTGAGCCAAATCCTTGTT } \\
\text { R: TCGGGTCGTGATTAATCGTT }\end{array}$ & Intron & 221 & - & 0 & - \\
\hline $\begin{array}{l}\text { Am2 } \\
\text { (AY232494) }\end{array}$ & $(\mathrm{CA})_{20}(\mathrm{AT})_{6}(\mathrm{AG})_{10}$ & $\begin{array}{l}\text { F: TGCTCCATCGATCTCTCCTT } \\
\text { R: GTGCATCATCCTCGCAGATT }\end{array}$ & 5'UTR & 165 & $96-191$ & 9 & 0.91 \\
\hline $\begin{array}{l}\text { Am3 } \\
\text { (AY236866) }\end{array}$ & $(\mathrm{CA})_{19}(\mathrm{AT})_{5}(\mathrm{AG})_{10}$ & $\begin{array}{l}\text { F: GACACAGTTGCCTCCGATTT } \\
\text { R: AGCTGTTGTTTATAGAGGCAGAA }\end{array}$ & CDS & 154 & $112-189$ & 11 & 0.87 \\
\hline $\begin{array}{l}\text { Am4 } \\
\text { (AY251054) }\end{array}$ & $(\mathrm{CGC})_{5}$ & $\begin{array}{l}\text { F: GTGAAGAACTCGTGGGGAAC } \\
\text { R: TGAGATGGTGAAGGGCTAGG }\end{array}$ & CDS & 209 & - & 0 & - \\
\hline $\begin{array}{l}\text { Am5 } \\
\text { (AY251055) }\end{array}$ & $(\mathrm{TCC})_{5}$ & $\begin{array}{l}\text { F: CTCACCTTTGAGCCTTCGAC } \\
\text { R: TACAGCAGCCTCACCTCCTC }\end{array}$ & CDS & 153 & - & 0 & - \\
\hline $\begin{array}{l}\text { Am6 } \\
\text { (AY555155) }\end{array}$ & $(\mathrm{AT})_{9}$ & $\begin{array}{l}\text { F: TCCTGAGCCAAATCCTTGTT } \\
\text { R: TCGGGTCGTGATTAATCGTT }\end{array}$ & CDS & 205 & - & 0 & - \\
\hline $\begin{array}{l}\text { Am7 } \\
\text { (DQ421809) }\end{array}$ & $(\mathrm{AG})_{31}$ & $\begin{array}{l}\text { F: GAAAAGGTAGGGTGTTTTCTCG } \\
\text { R: CGGAACAAGTACCTCGGTTG }\end{array}$ & CDS & 162 & $92-200$ & 9 & 0.90 \\
\hline $\begin{array}{l}\text { Am8 } \\
(\text { EF079870) }\end{array}$ & $(\mathrm{CA})_{11}(\mathrm{AT})_{9}(\mathrm{AG})_{13}$ & $\begin{array}{l}\text { F: GCGTAGGGTAGACACAGTTGC } \\
\text { R: CAGCTGTTGTTTATAGAGGCAGA }\end{array}$ & CDS & 154 & $121-198$ & 11 & 0.93 \\
\hline $\begin{array}{l}\text { Cm16 } \\
\text { (AM183320) }\end{array}$ & $(\mathrm{AG})_{19}$ & $\begin{array}{l}\text { F: ACTGGGCCACCAAATAAACA } \\
\text { R: ACGACCTGGACTTCATGACC }\end{array}$ & - & 207 & $206-299$ & 9 & 0.90 \\
\hline $\begin{array}{l}\mathrm{Zm} 32 \\
\quad(\mathrm{AJ} 700607)\end{array}$ & $(\mathrm{T})^{\wedge} 15 .(\mathrm{GTTTT})^{\wedge} 4$ & $\begin{array}{l}\text { F: GCCGATGTGTCCTCAGTGTA } \\
\text { R: AGCAAGGGCACAGAGAAGAA }\end{array}$ & - & 162 & $163-171$ & 3 & 0.86 \\
\hline
\end{tabular}

(Fig. 2). Among these SSRs, trinucleotide repeats were the most abundant (38.3\% of all SSRs), followed by interrupted compound repeats $(35.1 \%)$, and dinucleotide repeats $(22.5 \%)$. Of these, 60 working SSR primer pairs were further tested using the 28 genotypes. However, only the Zm32 locus was able to produce the expected amplicon size, with three polymorphic alleles detected at this locus; the amplicon size ranged from 163 to $171 \mathrm{bp}$, with a PIC value of 0.86 , and the profile was easy to interpret (Table 2; Fig. 1).

Establishing the optimal combination of SSR markers to discriminate Anthurium cultivars

Table 3 lists the allelic profiles of 28 genotypes for the four selected polymorphic SSR loci; a number of genotypes sharing the same profile vary at different loci. For example, the cultivar 'Cuba White' and 'Fantasia' had the same profiles within the loci of Am2, Am8 and Cm16, but revealed different allele markers at the Am7 locus. In particular, the 'Southern
Blush' cultivar had three specific profiles, including amplicons of 96 and $157 \mathrm{bp}$ at the Am2 locus, $111 \mathrm{bp}$ at Am7, 121 and 156 bp at Am8, and 214, 227 and 255 bp at Cm16 (Table 3).

Because the use of an individual SSR locus may not differentiate many cultivars, the combination of several loci could increase the efficiency when used for identification (Table 3; Table 4). Regarding the Am8 locus, only nine cultivars (or 11 genotypes) could be distinguished, whereas a combination of all the alleles within four selected loci in Table 4 can discriminate among 24 cultivars. Furthermore, 27 genotypes were discriminated by the combination of 65 SSR markers which amplified from 4 selected loci, with the exception of 'Tropical' and its mutant 'Tropical-P' with the same profile at each of the 4 loci (Tables 3,4 ).

Genetic diversity of Anthurium cultivars

The assessment of the genetic diversity of the 28 genotypes was based on the amplification of four selected SSR loci (Am2, Am7, Am8, and Cm16) 

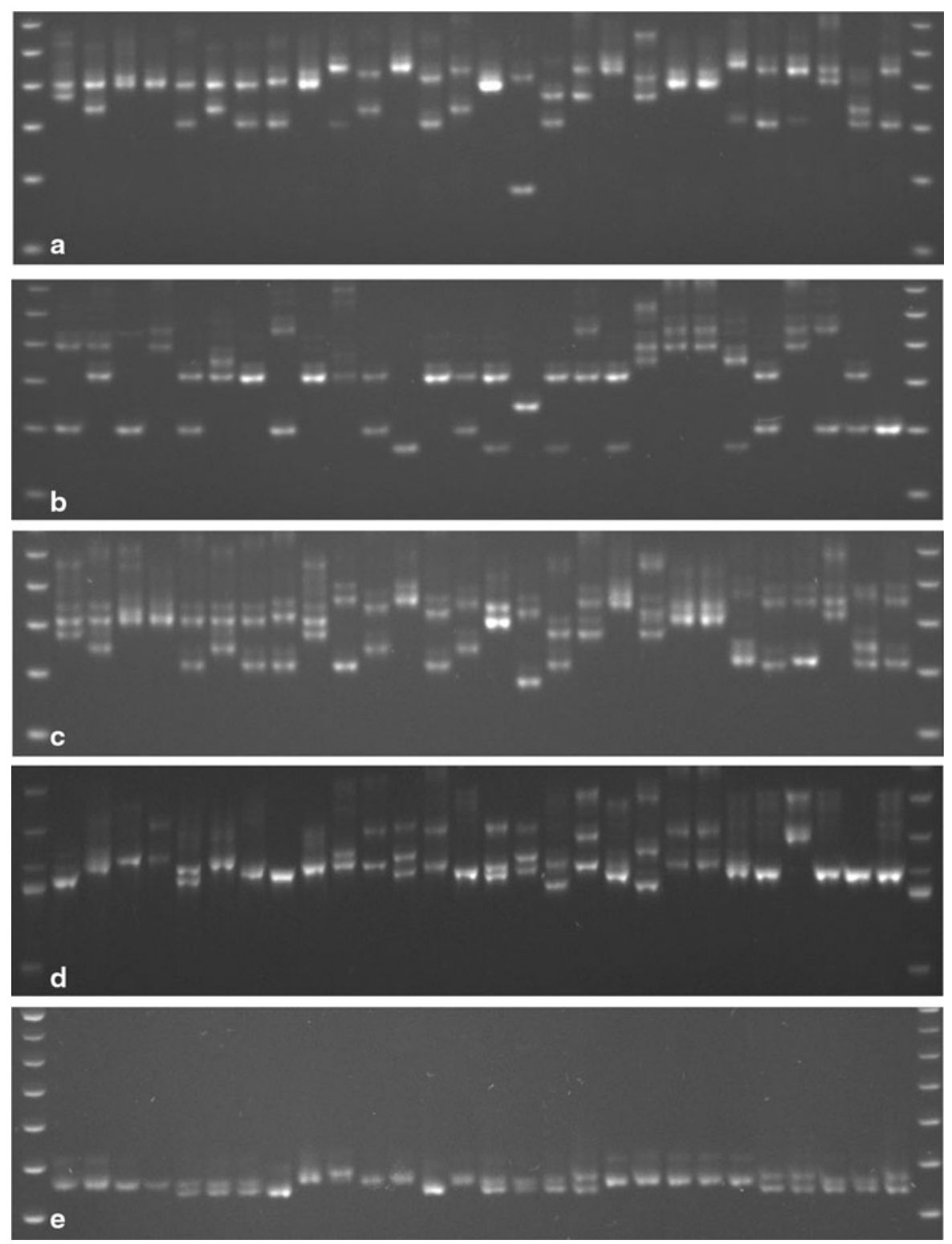

Fig. 1 PCR-amplified SSR profiles of the Am2 (a), Am7 (b), Am8 (c), Cm16 (d), and Zm32 (e) loci among 28 genotypes of Anthurium after separation on $6 \%$ polyacrylamide gels

giving a total of 65 polymorphic SSR markers. By the cluster analysis the 28 genotypes were separated into three main clusters, likely matching with their origin (i.e., breeders) (Fig. 3; Table 1), as the secondary main cluster (containing 12 genotypes) reveals that 9 of the commercial cultivars bred in the Netherlands grouped together with 3 progeny from TARI (Fig. 3; Table 1). However, 'Tropical', 'Tropical-P', 'Sonate'
(The order of the lanes from left to right follows the order from top to bottom in Table 1. Marker: 25 bp DNA step ladder (Promega) and low molecular weight DNA ladder (NEB))

and 'Anneke' which were bred in the Netherlands are separated in the third cluster (Fig. 3; Table 1). Moreover, 'TN01' and 'TN04' bred at TARI, in addition to 'Acropolis' and 'Tulip' appear to be differentiated from the other cultivars (Fig. 3). In particular, 'Southern Blush', bred at the University of Florida showed the most difference from the other 27 genotypes (Fig. 3). 
Fig. 2 Distribution of the primers designed and detected using Zantedeschia aethiopica ESTs, as based on the motif length

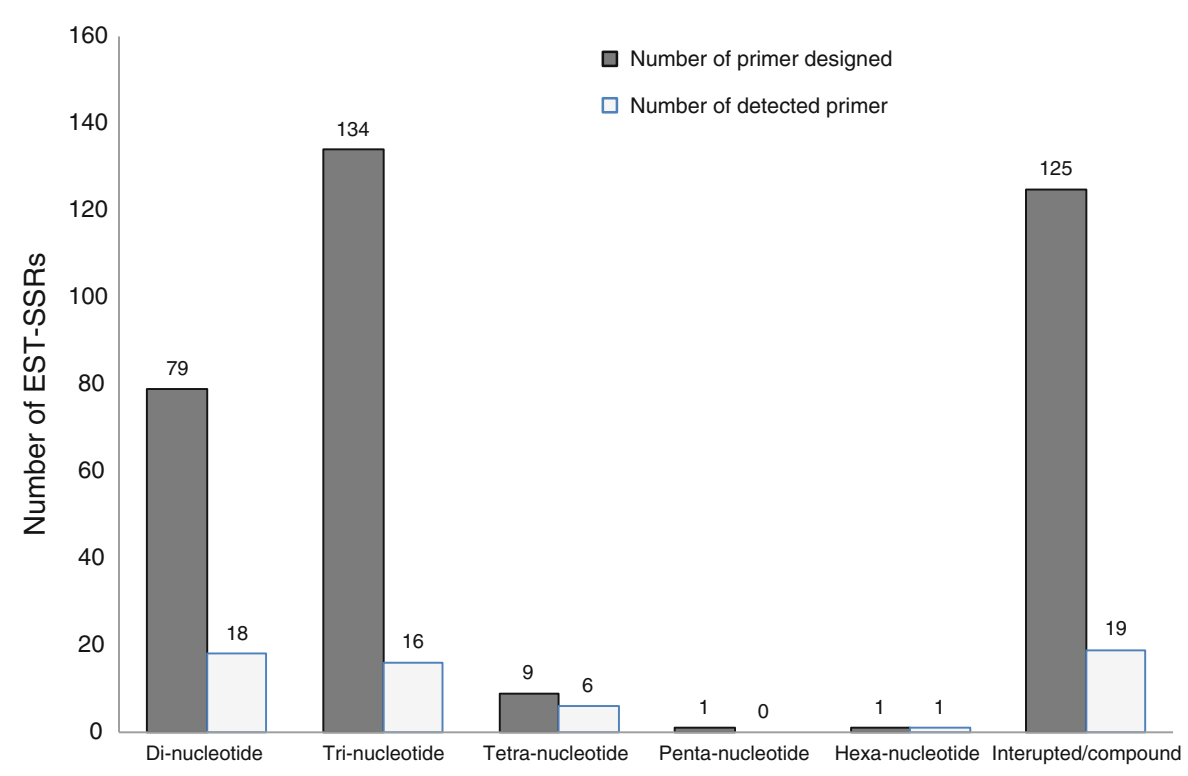

\section{Discussion}

The main goal of this study was to develop novel SSR markers in Anthurium. Primer pairs were constructed for 55 nucleotide sequences of Anthurium in GenBank, with four loci being successfully amplified. In addition, we selected two inter-genus SSR markers from Colocasia and Zantedeschia and assessed their transferability to Anthurium. Further PCR amplification indicates that the 28 genotypes of Anthurium consist of the characters for six SSR markers with significant polymorphism (Table 2). Most of the polymorphic loci are dinucleotide $(\mathrm{AG})_{n}$ motif repeats; three of the SSRs were located in coding regions, one was found in a 5'UTR and the other one was a genomic SSR (Table 2). It has been reported that a general property of plant genomes is a large abundance of AG/CT repeats. The functional significance of SSRs in genic regions in plants is unclear, but such homopurine-homopyrimidine stretches as $(\mathrm{AG})_{n} /(\mathrm{CT})_{n}$ in $5^{\prime} \mathrm{UTRs}$ have been reported to be related to the gene regulation genes involved in transcription, nucleic acid metabolism and the regulation of gene expression (Scaglione et al. 2009; Varshney et al. 2005). High proportions of AG/CT repeats have also been found in ESTs: e.g., pineapple (Wohrmann and Weising 2011), and kiwifruit (Fraser et al. 2004) and in almost all ESTs of various dicotyledonous plants (Kumpatla and Mukhopadhyay 2005). For example, the length of the polymorphism in a $(\mathrm{CT})_{n}$ microsatellite in the $5^{\prime} \mathrm{UTR}$ of the waxy gene in rice proved to be correlated to the amylose content (Ayers et al. 1997). However, a microsatellite located in a coding region can affect the activation of a gene and, therefore, the expression of a protein. It has been reported that the markers derived from transcribed sequences may be less polymorphic but more robust compared with genomic SSRs (Varshney et al. 2005).

Based on the number of alleles identified, the genicSSR markers developed in this study appear to be as polymorphic as genomic SSRs (Table 2) and, thus represent a valuable tool for the genetic characterization of Anthurium. However, the $60 \mathrm{SSR}$ primer pairs designed using the Zantedeschia aethiopica EST sequence and the 32 SSR primer pairs designed using the Colocasia eculenta microsatellite sequence resulted in a difference only one pair of primers $(<4 \%)$ and produced expected fragment. The results of this study indicate that the cross-genus transferability of the SSR primers for Anthurium designed using the ESTs of Zantedeschia aethiopica and the microsatellite sequences of Colocasia eculenta are extremely low. Because the report of Wohrmann and Weising (2011) indicated that the cross-species SSR marker transferability of Bromeliaceae is approximately $17.9 \%$, we speculate that the cross-species transferability may be higher than the cross-genus transferability in Araceae.

To use microsatellite markers for cultivar differentiation, we present four representative polymorphic SSR loci showing easily scorable alleles and the 
Table 3 Allelic sizes and profiles of four selected SSR loci for the 28 genotypes of Anthurium

Table 4 Efficiency of the optimal combination of the four selected informative SSR loci to discriminate 27 Anthurium genotypes

\begin{tabular}{|c|c|c|c|c|}
\hline \multirow[t]{2}{*}{ Cultivar/genotype } & \multicolumn{4}{|c|}{ Specific alleles (bp) in the selected SSR locus } \\
\hline & $\begin{array}{l}\text { Am2 } \\
\text { (AY232494) }\end{array}$ & $\begin{array}{l}\text { Am7 } \\
\text { (DQ421809) }\end{array}$ & $\begin{array}{l}\text { Am8 } \\
(\mathrm{EF} 079870)\end{array}$ & $\begin{array}{l}\text { Cm16 } \\
(\mathrm{AM} 183320)\end{array}$ \\
\hline Acropolis & $144 ; 152$ & $100 ; 149$ & $144 ; 152 ; 162 ; 190$ & 206 \\
\hline Alexis & $135 ; 152$ & $128 ; 149$ & $137 ; 152 ; 162$ & 214 \\
\hline Anneke & 152 & 100 & 152 & 221 \\
\hline Atlantis & 152 & $149 ; 161$ & 152 & $221 ; 255$ \\
\hline Carnaval & $127 ; 152$ & $100 ; 128$ & $129 ; 152 ; 162$ & $206 ; 214$ \\
\hline Champion & $135 ; 152$ & $128 ; 138$ & $137 ; 152 ; 162$ & 214 \\
\hline Cuba White & $127 ; 152$ & 128 & $129 ; 152 ; 162$ & 214 \\
\hline Fantasia & $127 ; 152$ & $100 ; 161$ & $129 ; 152 ; 162$ & 214 \\
\hline Fla-Exotic & $152 ; 157$ & 128 & $144 ; 152 ; 162 ; 190$ & 214 \\
\hline Lady Jane & $127 ; 163$ & $128 ; 200$ & $129 ; 166 ; 174$ & $221 ; 227$ \\
\hline Lunette & $135 ; 163$ & $100 ; 128$ & $137 ; 162$ & $221 ; 255$ \\
\hline Marian Seefurth & 163 & 92 & $166 ; 174$ & $214 ; 227 ; 255$ \\
\hline Merengue & $127 ; 157$ & 128 & $129 ; 156 ; 166$ & $221 ; 255$ \\
\hline Midori & $135 ; 163$ & $100 ; 128$ & $137 ; 162$ & 214 \\
\hline Sonate & 152 & $92 ; 128$ & $152 ; 162$ & $214 ; 221 ; 255$ \\
\hline Southern Blush & $96 ; 157$ & 111 & $121 ; 156$ & $214 ; 227 ; 255$ \\
\hline TN01 & $127 ; 144$ & $92 ; 128$ & $129 ; 144 ; 152$ & $206 ; 221$ \\
\hline TN02 & $144 ; 163$ & $128 ; 161$ & $144 ; 152 ; 162 ; 174$ & $221 ; 247 ; 299$ \\
\hline TN03 & 163 & $92 ; 128$ & $162 ; 166$ & $214 ; 286$ \\
\hline TN04 & $144 ; 157 ; 191$ & $138 ; 149 ; 181$ & $144 ; 156 ; 166 ; 190$ & $206 ; 234 ; 299$ \\
\hline Tropical & 152 & $149 ; 161$ & $152 ; 162$ & $221 ; 255$ \\
\hline Tropical-P & 152 & $149 ; 161$ & $152 ; 162$ & $221 ; 255$ \\
\hline Tulip & $127 ; 167$ & $92 ; 138$ & 129 & 214 \\
\hline Champagne & $127 ; 163$ & $100 ; 128$ & $129 ; 162$ & 214 \\
\hline 123(Nette) & $127 ; 163$ & $149 ; 161$ & $129 ; 162$ & $247 ; 299$ \\
\hline 943954-1 & $152 ; 163$ & $100 ; 161$ & $156 ; 162 ; 198$ & 214 \\
\hline $943954-2$ & $127 ; 135 ; 157$ & $100 ; 128$ & $129 ; 137 ; 166$ & 214 \\
\hline $943954-4$ & $127 ; 163$ & 100 & $129 ; 162$ & 214 \\
\hline $\begin{array}{l}\text { Number of cultivars } \\
\text { discriminated }\end{array}$ & 8 & 9 & 9 & 10 \\
\hline $\begin{array}{l}\text { Number of SSR allele markers } \\
\text { within } 28 \text { genotypes }\end{array}$ & 16 & 15 & 18 & 16 \\
\hline
\end{tabular}

\begin{tabular}{llll}
\hline $\begin{array}{l}\text { Numbers of } \\
\text { combination }\end{array}$ & Locus and combination & $\begin{array}{l}\text { Number of cultivars } \\
\text { distinguished }\end{array}$ & $\begin{array}{l}\text { Total number of } \\
\text { genotypes distinguished }\end{array}$ \\
\hline 1 & $\mathrm{Am} 8$ & 9 & 11 \\
2 & $\mathrm{Am} 8+\mathrm{Am} 7$ & 12 & 14 \\
3 & $\mathrm{Am} 8+\mathrm{Am} 7+\mathrm{Am} 2$ & 13 & 14 \\
4 & $\mathrm{Am} 8+\mathrm{Am} 7+\mathrm{Am} 2+\mathrm{Cm} 16$ & 24 & 27 \\
\hline
\end{tabular}

profiles of 28 Anthurium genotypes (Table 3; Fig. 1). A diagnostic banding pattern could be found for all 27 of the genotypes except for a mutant of 'Tropical'.
It is suggested that SSR markers are suitable cultivarspecific markers of Anthurium; in addition, the SSR allele profiles can provide effective tools for 
Fig. 3 Dendrogram presenting the association among 28 Anthurium genotypes based on the UPGMA cluster analysis of 65 amplified SSR markers (an estimated similarity coefficient indicated on the position of the cluster node)
Similarity coefficient (\%)

Cultivar/genotype

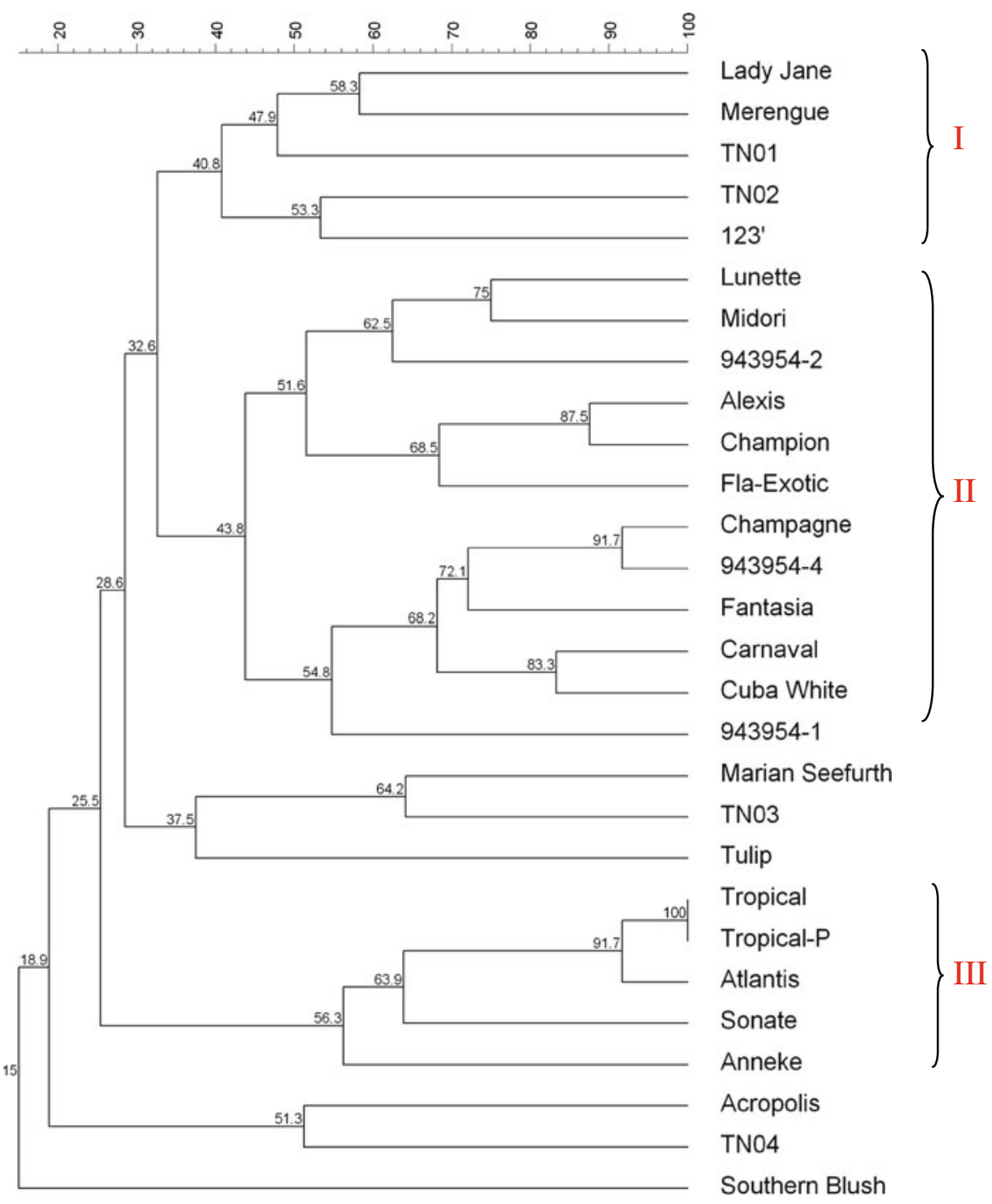

differentiating or fingerprinting Anthurium. Furthermore, the higher is the average number of polymorphic markers, the higher is the characterization among genotypes. Microsatellite markers have also been shown to be highly polymorphic and efficient for phylogenetic studies (Ashkenazi et al. 2001). In this study, the genetic diversity analysis revealed that 'Southern Blush', which originated from the University of Florida was different from the other 27 genotypes (Fig. 3). According to a related report, 'Southern Blush' is a hybrid of Anthurium andraenum and Anthurium amnicola (Henny et al. 1988); therefore, it differs significantly from the other genotypes that belong to Anthurium andraenum. Performing cluster analysis of genetic similarity using SSR markers could help to distinguish genomic backgrounds and resources.

In conclusion, we developed and characterized the first six microsatellite markers for use in Anthurium fingerprinting and genetic diversity studies. Furthermore, we have shown a high level of polymorphism of the Anthurium SSR loci. Through further development in the future, these SSR markers should provide an efficient tool for cultivar discrimination and genetic diversity assessment and will be beneficial for markerassisted selection in Anthurium. 
Acknowledgments This work was supported by grants 100AS-1.1.9-CI-C1. At TARI, this project was founded by the Council of Agriculture (COA), Executive Yuan, Taiwan.

Open Access This article is distributed under the terms of the Creative Commons Attribution License which permits any use, distribution, and reproduction in any medium, provided the original author(s) and the source are credited.

\section{References}

Ashkenazi V, Chani E, Lavi U, Levy D, Hillel J (2001) Development of microsatellite markers in potato and their use in phylogenetic and fingerprinting analyses. Genome 44:50-62

Ayers NM, McClung AM, Larkin PD, Bligh HFJ, Jones CA, Park WD (1997) Microsatellites and a single nucleotide polymorphism differentiate apparent amylose classes in an extended pedigree of US rice germplasm. Theor Appl Genet 94:773-781

Condit R, Hubbell SP (1991) Abundance and DNA sequence of two-base repeat regions in tropical tree genomes. Genome 34:66-71

Faircloth BC (2008) MSATCOMMANDER: detection of microsatellite repeat arrays and automated, locus-specific primer design. Mol Ecol Res 8:92-94

Frary A, Xu Y, Lin J, Mitchell S, Tedeschi E, Tanksley S (2005) Development of a set of PCR-based anchor markers encompassing the tomato genome and evaluation of their usefulness for genetics and breeding experiments. Theor Appl Genet 111:291-312

Fraser LG, Harvey CF, Crowhurst RN, De Silva HN (2004) EST derived microsatellites from Actinidia species and their potential for mapping. Theor Appl Genet 108:1010-1016

Gomez SM, Denwar NN, Ramasubramanian T, Simpson CE, Burow G, Burke JJ, Puppala N, Burow MD (2008) Identification of peanut hybrids using microsatellite markers and horizontal polyacrylamide gel electrophoresis. Peanut Sci 35:123-129

Gong L, Geng Z (2010) EST-SSR markers for gerbera (Gerbera hybrida). Mol Breed 26:125-132

Guilford P, Prakash S, Zhu JM, Rikkerrink E, Gardiner S, Bassett H, Foster R (1997) Microsatellite in Malus $\times$ domestica (apple): abundance, polymorphism and cultivar identification. Theor Appl Genet 94:249-254

He C, Poysa V, Yu K (2003) Development and characterization of simple sequence repeat (SSR) markers and their use in determining relationships among Lycopersicon esculentum cultivars. Theor Appl Genet 106:363-373

Henny RJ, Poole RT, Connover CA (1988) "Southern Blush" Anthurium. HortScience 23:922-923

Iqbal MJ, Paden DW, Rayburn AL (1995) Assessment of genetic relationships among rhododendron species, varieties and hybrids by RAPD analysis. Sci Hortic 63:215-223

Kamemoto H, Kuehnle AR (1996) Breeding Anthuriums in Hawaii. University of Hawaii Press, Honolulu, p 132

Kobayashi RS, Brewbaker JL, Kamemoto H (1987) Identification of Anthurium andraeanum cultivars by gel electrophoresis. J Am Soc Hortic Sci 112:164-167
Kumpatla SP, Mukhopadhyay S (2005) Mining and survey of simple sequence repeats in expressed sequence tags of dicotyledonous species. Genome 48:985-998

McCouch SR, Teytelman L, Xu Y, Lobos KB, Clare K, Walton M, Fu B, Maghirang R, Li Z, Xing Y, Zhang Q, Kono I, Yano M, Fjellstrom R, DeClerck G, Schneider D, Cartinhour S, Ware D, Stein L (2002) Development and mapping of 2240 new SSR markers for rice (Oryza sativa L.). DNA Res 9:199-207

Mujaju C, Sehic J, Werlemark G, Garkava-Gustavsson L, Fatih M, Nybom H (2010) Genetic diversity in watermelon (Citrullus lanatus) landraces from Zimbabwe revealed by RAPD and SSR markers. Hereditas 147:142-153

Nei M, Li WH (1979) Mathematical model for studying genetic variation in terms of restriction endonucleases. Proc Natl Acad Sci USA 76:5269-5273

Nowbuth P, Khittoo G, Bahorun T, Venkatasamy S (2005) Assessing genetic diversity of some Anthurium andraeanum Hort. Cut-flower cultivars using RAPD Markers. Afr J Biol 4:1189-1194

Rajwant K, Kalia MK, Rai S, Kalia R Singh, Dhawan AK (2011) Microsatellite markers: an overview of the recent progress in plants. Euphytica 177:309-334

Rozen S, Skaletsky HJ (2000) Primer3 on the WWW for general users and for biologist programmers. In: Krawetz S, Misener S (eds) Bioinformatics methods and protocols: methods in molecular biology. Humana Press, Totowa

Saal B, Wricke G (1999) Development of simple sequence repeats in rye (Secale cereale L.). Genome 42:964-972

Scaglione D, Acuadro A, Portis E, Taylor CA, Lanteri S, Knapp SJ (2009) Ontology and diversity of transcript-associated microsatellites mined from a globe artichoke EST database. BMC Genomics 10:454

Tantasawat P, Trongchuen J, Prajongjai T, Seehalak W, Jittayasothorn Y (2010) Variety identification and comparative analysis of genetic diversity in yardlong bean (Vigna unguiculata spp. sesquipedalis) using morphological characters, SSR and ISSR analysis. Sci Hortic 124:204-216

Temnykh S, DeClerck G, Lukashova A, Lipovich L, Cartinhour S, McCouch S (2001) Computational and experimental analysis of microsatellites in rice (Oryza sativa L.): frequency, length variation, transposon associations, and genetic marker potential. Genome Res 11:1441-1452

Varshney RK, Graner A, Sorrells ME (2005) Genic microsatellite markers in plants: features and applications. Trends Biotechnol 23:48-55

Wang Z, Weber JL, Zhong G, Tanksley SD (1994) Survey of plant short tandem DNA repeats. Theor Appl Genet 88:1-6

Wang JY, Chung KC, Fan MJ (2001) Comparative analysis of genetic similarity among Anthurium cultivars by using ISSR and RAPD makers. J Taiwan Agric Res 50:54-67 (in Chinese with English abstract)

Wohrmann T, Weising K (2011) In silico mining for simple sequence repeat loci in a pineapple expressed sequence tag database and cross-species amplification of EST-SSR markers across Bromeliaceae. Theor Appl Genet 123: 635-647

Zhang L, Li Z, Wang Y, Jiang Z, Wang S, Huang H (2010) Vitamin $C$, flower color and ploidy variation of hybrids from a ploidy-unbalanced Actinidia interspecific cross and SSR characterization. Euphytica 175:133-143 
Zorrilla-Fontanesi Y, Cabeza A, Torres M, Botella MA, Valpuesta V, Monfort A, Sa'nchez-Sevilla JF, Amaya I (2011) Development and bin mapping of strawberry genic-SSRs in diploid Fragaria and their transferability across the Rosoideae subfamily. Mol Breed 27:137-156 